\title{
TRAS LOS “SIGNOS DE LA PROFECÍA": A PROPÓSITO DE LAS FUENTES IDEOLÓGICAS Y LITERARIAS DEL FECHO DE BULUQIYA Y SU PERVIVENCIA EN LA LITERATURA PIADOSA DE LOS MORISCOS
}

Jorge Pascual Asensi*

El relato aljamiado-morisco conocido como "Capítulo de Buluqiya y de lo que fue de su fecho" se conserva en dos manuscritos misceláneos de la colección de la antigua Junta para la Ampliación de Estudios (hoy del CSIC), correspondientes a los códices núms. VIII y LVII de su catálogo. La primera de las dos versiones (ms. VIII) se halla inserta en una obra de carácter general que lleva el título de Castigos para las gentes ${ }^{1}$ y ocupa los fols. $81 \mathrm{r}-107 \mathrm{v}$ (sic), su estado de conservación es bueno, salvo lagunas ocasionales, y está escrito en letra magrebí ${ }^{2}$. El manuscrito carece de fecha, pero todo parece indicar que se trata de una copia de principios del siglo $\mathrm{XVII}^{3}$. El segundo texto conservado comprende los fols. 9r-32r de un códice (ms. LVII) sin título,

\footnotetext{
* Universidad de Alicante.

1. El manuscrito fue editado íntegramente por $\mathrm{M}^{\mathrm{a}} \mathrm{J}$. FERNÁNDEZ, Libro de los Castigos (Ms. aljamiado $n^{\circ} 8$ de la Biblioteca de la Junta. Edición, introducción, estudio lingüístico, glosario y notas), Universidad de Oviedo, 1987 (tesis doctoral inédita).

2. El texto de Buluqiya conservado en este manuscrito ha sido recientemente editado, con transcripción modernizada e introducción al mismo, por L. LÓPEZ-BARALT, El viaje maravilloso de Buluqiya a los confines del universo, Madrid, 2004. La edición filológica a partir de todos los textos conservados ha sido igualmente objeto de mi Memoria de 3er Ciclo: Estudio y edición crítica del relato aljamiado-morisco "Capítulo de Buluqiya y de lo que fue de su fecho», Universidad de Alicante, marzo de 2005.

3. J. Ribera y M. Asín Palacios, Manuscritos árabes y aljamiados de la Biblioteca de la Junta. Noticias y extractos por los alumnos de la Sección de Árabe, Madrid, 1912, p. 44.
} 
igualmente escrito en letra magrebí, y que agrupa un conjunto de recontamientos, hadīces y alfadīlas. Es el más antiguo de ambos, puesto que se da la data de $1587^{4}$ en una última guarda conservada en caracteres latinos. Su estado de conservación es regular, ya que parte del texto ha sido dañado por la humedad ${ }^{5}$.

Dos han sido, pues, los manuscritos que han guardado veladamente el relato que aquí nos ocupa hasta su descubrimiento, en un falso techo de un caserón en Almonacid de la Sierra (Zaragoza) y junto a otro gran número de documentos en escritura aljamiada, a finales del siglo $\mathrm{XIX}^{6}$. Ambas versiones comparten una misma filiación manuscrita, seguramente con respecto a otra $u$ otras anteriores perdidas, como lo demuestra el hecho de que el más moderno de los dos (ms. catalogado como Junta VIII), fechado a principios del s. XVII, aún conserve algunos rasgos lingüísticos arcaizantes, como por ejemplo la conservación en algunas palabras de la f-inicial etimológica, que ya no poseía el más antiguo de ellos, cuya fecha de redacción se remonta a 1587 (ms. Junta LVII) ${ }^{7}$.

Esta hipotética diversificación de los soportes manuscritos no parece sino indicarnos el especial interés que debió de suscitar entre los moriscos el "Fecho" de Buluqiya, cuyo texto original árabe se puede encontrar en la obra de Qișaṣ al-anbiyā' (Historias de los Profetas) de Abū Isḥāq Aḥmad ibn Muhammad at-Ta'labī (m. 1036) ${ }^{8}$. Tal interés, como se observará a continuación, respondía, más que a un gusto estético o a una fijación en sus rasgos artísticos advertidos por López-Baralt ${ }^{9}$, a la adscripción de unos valores ideológicos fundamentados sobre la fe musulmana, pero cristalizados a su vez en la cultura morisca como consecuencia de la hostil situación socio-religiosa a la que esta comunidad his-

4. A. VeSPERTINO RODRíGUEZ, «Una aproximación a la datación de los manuscritos aljamiadomoriscos», Estudios Románicos. Homenaje al Prof. Rubio, II, Murcia, 5 (1987-1989), 1436, n. 100.

5. Véase J. Ribera y M. Asín PAlacios, op. cit., 203.

6. Sobre su hallazgo véase F. CODERA, «Almacén de un librero morisco descubierto en Almonacid de la Sierra», Boletín de la Real Academia de Historia, 5 (1884), pp. 269-276. La mayor parte de estos textos fueron puestos a salvo por Pablo Gil, coleccionista de textos aljamiados, pasando con posterioridad a formar parte del catálogo de manuscritos de la Junta de Ampliación de Estudios de Madrid.

7. Para un más detallado análisis lingüístico del texto véase M. Alvar y F. de la GRANJA, «Apostillas lingüísticas al Fecho de Buluqiya», Homenaje a Francisco Ynduráin, Zaragoza, 1972, pp. 23-39.

8. Cito en adelante por la edición de Muhammad SAYYID, Qișaṣ al-anbiyā' al-musammà 'arā'is almaŷâlis, El Cairo, 2001, pp. 475-486. Igualmente, he encontrado sendas recensiones del relato en an-Nuwayrī (m. 1333), Nihāyat al-arab fi funūn al-adab, quien cita al anterior como fuente directa; y, de forma extractada, en Ibn Iyās (m. 1524), Badā' $i^{\prime} a z-z u h \bar{u} r$ fì waq $\bar{a}^{\prime} i^{\prime}$ ad-duhūr, Beirut, 1992, pp. 155-157. Igualmente, el relato aparece tardíamente en la Recensión Egipcia de Zotenberg de las Mil y una noches (Alf layla wa-layla), inserto entre las noches núms. 486-533 y notablemente amplificado; para una descripción de sus contenidos véase V. CHAUviN, Bibliographie des ouvrages arabes ou relatifs aux arabes publiés dans l'Europe Chrétienne de 1810 à 1885, Lieja, 1900-1909, VII, pp. 54-59, e igualmente N. ElissÉEFF, Thèmes et motifs des Mille et une nuits. Essai de classification, Beirut, 1949, 198, n 123, e índices 229.

9. L. López-BARALT, op. cit., 34 et passim. 
pánica se veía continuamente enfrentada. Es a ello a lo que me voy a referir en el presente estudio, no sin antes presentar una sinopsis de relato:

La historia nos sitúa en Egipto, en una época posterior a la muerte del sabio rey Salomón, en tiempos de un gobernante judío llamado Uxri (Uxiyya) ${ }^{10}$. Tras la muerte de éste, es su hijo Buluqiya quien ha de sucederle en el gobierno del Pueblo de Israel. Sin embargo, al ir a revisar los tesoros de su padre, encuentra oculto en un cofre sellado un fragmento del libro de la Torá que anuncia la venida al mundo de Mahoma. Es entonces cuando Buluqiya da la noticia a sus súbditos y decide abandonar su país para emprender la búsqueda del futuro Profeta de los musulmanes.

Así comienza la primera parte de su viaje, desde Egipto hasta Siria (Xam). En esta primera travesía por mar Buluqiya llega a una isla en la que encuentra unas enormes serpientes que dicen ser las serpientes del infierno, las cuales son expulsadas a la tierra por la propia respiración de aquél, al tiempo que afirman conocer el nombre de Mahoma. En una segunda isla encuentra a Tamalih (Tamlija), la reina de aquellas serpientes. Esta primera etapa del viaje acaba con la llegada final de Buluqiya a Jerusalén (Bayt al-Maqdis), en donde se encuentra con el sabio judío 'Affan, quien, tras conocer el propósito de Buluqiya de encontrar a Mahoma, le da la noticia de que éste no será enviado hasta pasado un largo período de tiempo que jamás podría alcanzar a vivir. No obstante, 'Affan le sugiere el modo de hacerlo: irán ambos a la tumba de Salomón, la cual se halla más allá de los siete mares, para tomar su anillo-talismán. Con este anillo conseguirán el poder mágico del sabio rey judío y, no de otro modo, alcanzar el tiempo de Mahoma. Sin embargo, para poder atravesar los siete mares, ambos tendrán que apoderarse de una planta mágica cuyo zumo, untándolo en los pies, permite caminar sobre las aguas, pero de cuya existencia solamente sabe la reina de las serpientes.

Buluqiya, ansioso por conseguir su propósito, guía a 'Affan hasta el lugar en donde había encontrado a la reina de las serpientes, a fin de capturarla para que les lleve hasta la planta mágica. De este modo, una vez conseguida la hierba mágica, deciden liberar a la serpiente y se adentran en el mar caminando sobre su superficie. Ambos atraviesan velozmente los siete mares hasta que llegan a una gran montaña en la que existe una gruta que guarda el cuerpo de Salomón. Cuando los dos peregrinos llegan ante la presencia de Salomón, 'Affan pide a Buluqiya que recite la Torá y los nombres de Dios mientras él toma el anillo del rey. En esto, una gran serpiente que vela los restos de Salomón advierte a 'Affan del peligro que corre, pero éste desoye tal advertencia y, en un momento en el que Buluqiya descuida su lectura, es aniquilado por las llamas que arroja la propia serpiente.

Tras el funesto percance, Buluqiya dialoga con el ángel Gabriel, quien había descendido de los cielos durante la escena anterior, y le indica que ha sido salvado de la muerte sólo por su devoción a Mahoma. Consciente el noble judío de que jamás podrá conseguir la vida eterna para alcanzar el tiempo del Profeta, se

10. Coloco entre paréntesis los nombres propios empleados por el autor árabe de las Qiṣaș, siempre y cuando difieren de la tradición aljamiada. 
vuelve por los siete mares hasta que llega a una isla, trasunto del paraíso, en la que encuentra a Mahzun (Sajr), el rey de los genios creyentes, quien narra la historia de la creación de los genios y el diablo.

En este punto, y tras dejar al rey de los genios, comienza para Buluqiya otro tipo de viaje diferente al que le había llevado hasta su presencia. Así, tras montar el héroe un caballo volador proporcionado por el propio rey de los genios, Buluqiya emprende un periplo por las regiones del más allá, en donde observa con sus propios ojos un universo de formas eternas, al tiempo que conoce a los ángeles y seres que lo habitan, quienes sirven a Dios o mueven los órdenes del mundo, recordándole en todo momento la futura -aunque efectiva- existencia de Mahoma. Cansado de recorrer los confines del universo y separado de su patria por cientos de años, Buluqiya será transportado hasta su casa de manera fulgurante por al-Jaḍir, conocido personaje de otras leyendas islámicas, al cabo de lo cual manda poner su historia por escrito para que el Pueblo de Israel conozca el verdadero alcance de su descubrimiento.

Por sus características intrínsecas, el relato de Buluqiya puede relacionarse genéricamente con un conjunto de textos piadosos islámicos -todos ellos recogidos en la tradición morisca- en los que se nos narra la conversión al Islam de personajes judíos o cristianos o, cuando menos, su reconocimiento formal como la verdadera y única religión. Estos relatos aparecen atribuidos a algunas de las primitivas autoridades sobre historias bíblicas en el Islam, a su vez musulmanes conversos de origen judío, como Ka‘b al-Aḥbār (m. 654) o 'Abd Allāh b. Salām (m. 663), quien se presenta como autoridad en el relato de Buluqiya. En ocasiones son ellos mismos quienes protagonizan la historia de sus conversiones. Pero lo más destacado es que, en todas estas narraciones, la parábola de la conversión se presenta fundamentada por el reconocimiento de los "signos proféticos" de Mahoma en la Torá y en el Evangelio o por la vocación islámica de sus antiguas Escrituras.

\section{LOS "SIGNOS DE LA PROFECÍA"}

El relato de Buluqiya explora un tema literario, el del signo profético encontrado en las Escrituras, que ocupa, en su variable ideológica y apologética, un lugar prominente en la summa theologica de los musulmanes. No obstante, la tradición árabe desarrolla al respecto un tipo de obras conocidas genéricamente como dalā'il o a 'lām an-nubuwwo ("pruebas" o "signos de la profecía") ${ }^{11}$ cuyos autores tratan la figura de Mahoma, los milagros por él realizados o la revelación de su mensaje, como pruebas que autentifican por sí mismas su

11. Véase S. StroumsA, «The Signs of Prophecy: The Emergence and Early Development of a Theme in Arabic Theological Literature», Harvard Theological Review, 78:1-2 (1985), pp. 101-114. 
personalidad profética ${ }^{12}$. La primera de estas obras conservada en la tradición islámica, el Huŷây an-nubuwwo de al-Ŷāịiz (m. 869), enumera ya dos categorías de prueba ${ }^{13}$, ambas dependientes del intelecto ('aql) ${ }^{14}$, que serán fundamentales en el desarrollo del género. En primer lugar, aquéllas que se deducen racionalmente de la experiencia (iyān zāhir), que se correspondería principalmente con los milagros efectuados por el Profeta ${ }^{15}$. Habrá de observarse, no obstante, que la noción de milagro en el Islam es contestataria de los argumentos que entran a valorarse para distinguir la verdadera profecía, interpelados del Deuteronomio (12:2-7; 18:15-22), y que habría constituido la base dogmática fundamental en torno a las "pruebas de la profecía" en la tradición judeocristiana ${ }^{16}$. Por otro lado, según el propio al-Ŷāhiz, existe un segundo tipo de "pruebas" proféticas, que son las que se derivan de la incontestable tradición (jabar qāhir), refiriéndose a las tradiciones relacionadas con el Profeta y sus acciones milagrosas y con la transmisión del Libro revelado ${ }^{17}$. La revelación del Libro, el Corán, ya constituye de por sí el definitivo milagro atribuido a Mahoma, pues su inimitabilidad ( $\left.i^{\prime} \hat{y} \bar{a} z\right)$ supondría uno de los rasgos proféticos incontestables y, por ende, un importante argumento apologético del Islam frente a la tradición judeocristiana ${ }^{18}$. El Corán sería, por tanto, palabra de Dios en contenido, pero igualmente en expresión.

Partiendo de esta última idea, y en ligazón conceptual con el motivo descrito en el "Fecho" de Buluqiya, este género de dalā'il desarrolla, a partir de las invocaciones coránicas, la argumentación de la exégesis bíblica como prueba de la profecía mahomética ${ }^{19}$. Esta clase de argumentación, preponderante en las obras tardías de polémica, desarrolla la idea de que algunos pasajes de la Torá y el Evangelio aluden a Mahoma y al advenimiento del Islam de una manera más o menos explícita, postura basada principalmente en el argumento del paráclito sobre los versículos del Evangelio de Juan 14:16-17 y 16:7-15²0; pero

12. Véase H. LAZARUS-YAFEH, Intertwined Worlds. Medieval Islam and Bible Criticism, New Jersey, 1992, p. 79.

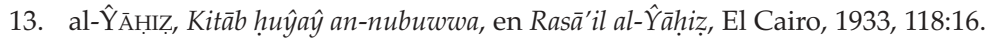

14. Ibídem, 118:17-22.

15. Ibídem, 139:19 ss.

16. Cfr. sendos trabajos de S.H. GrIfFITH, "Comparative Religion in the Apologetics of the First Christian Arabic Theologians», Proceedings of the Patristic, Medieval and Renaissance Conference, 4 (1979), p. 80; y «'Ammār al-Bașrī's Kitāb al-Burhān: Christian Kalām in the First Abbasid Century», Le Muséon, 96 (1983), p. 165.

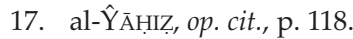

18. Ibídem, 136:1-7; 138:14-17; 141:20 ss.; 143:4 ss.; a este respecto véase igualmente H. LAZARUSYAFEH, op. cit., pp. 14-18.

19. Véase H. LAZARUS-YAFEH, «Muslim Bible Exegesis: The Prediction of Muhammad and Islam», en Intertwined Worlds, pp. 73-110.

20. Véase M. de EPALZA, Jesús entre judios, cristianos y musulmanes hispánicos (siglos VI-XVII), Granada, 1999, pp. 128-132. 
igualmente en el hecho de que el Antiguo Testamento proyecte una serie de tipos o figuras solamente comprensibles por la efectiva revelación del texto coránico, pues éstos harían referencia a ciertos aspectos de la ritualidad y el culto islámicos, que los dota a su vez de una consagración histórica ${ }^{21}$.

Pese a que el empleo y la citación textual de la Biblia como modo de probar la veracidad de la revelación islámica aparece documentado ya en obras del siglo IX, especialmente en Ibn Rabban (m. ca. 865) e Ibn Qutayba (m. 889) ${ }^{22}$, el uso del criterio tipológico como recurso hermenéutico ${ }^{23}$ sólo se extiende entre los autores musulmanes a partir de los siglos X y XI, al tiempo que el debate sobre las "pruebas de la profecía" se abría a otros géneros no específicos, como la historiografía ( $\left.t a^{\prime} r \bar{i} j\right)$, la exégesis coránica ( $t a f s \bar{i} r$ ) o la heresiografía islámica (milal wa-nihal) ${ }^{24}$. Por lo que respecta a este empleo del recurso tipológico en relación con la personalidad de Mahoma, los autores islámicos lo aplican igualmente por simple transposición del supuesto significado cristológico de un versículo o, cuando menos, entendiendo la alusión bíblica a Jesús y a Mahoma por igual $^{25}$. No obstante, en la teología islámica existe un escaso desarrollo de la relación tipológica, puesto que la interpretación bíblica nunca adquirió tanta importancia en el Islam como en la testimonia cristiana, y ésta sólo se dio en autores musulmanes polemistas como apoyo a la interpretación de algunos pasajes bíblicos que probaban la profecía de Mahoma ${ }^{26}$. El Corán tampoco

21. Véase H. LAZARUS-YAFEH, op. cit., pp. 93-98.

22. Véase S. Stroumsa, op. cit., p. 106. Parcialmente conservadas o no exentas de polémica por su autenticidad han pervivido sus obras respectivas Kitāb ad-dīn wa-d-dawla y Dalā'il an-nubuwwa (véase H. LAZARUS-YAFEH, op. cit., p. 80). No obstante, y pese a los argumentos en contra, el propio Ibn Qutayba aparece en la tradición islámica como el primero en citar una traducción de la Biblia al árabe: véase G. LECOMTE, «Les Citations de l’Ancien et du Nouveau Testament dans l'oeuvre d'Ibn Qutayba», Arabica, 5 (1958), pp. 34-46. Igualmente, Ibn al-Nadīm cita los libros perdidos de varios autores: Bišr b. al-Mu'tamir y Abū Sahl an-Nūbajtī (cfr. Fihrist, Beirut, 1978, pp. 230 y 331 respectivamente).

23. Este criterio tipológico fue ampliamente empleado en los textos exegéticos cristianos por los Padres de la Iglesia y durante la Edad Media; véase K.J. WoollCOMBE, «The Biblical Origins and Patristic Development of Typology», en J. LAMPE y K.J. Woollcombe (eds.), Essays of Typology, Londres, 1957, pp. 39-75. La premisa básica consistía en que, para entender correctamente el Antiguo Testamento, era necesario referirse al Nuevo Testamento, y viceversa. Esto sería así porque muchos de los motivos narrados en el AT son "tipos" o "figuras" de motivos que aparecen en el NT. Dicho de otro modo, los acontecimientos y caracteres que se explicitan en el AT adquieren su valor de veracidad y son explicables sólo poniéndolos en relación con el NT. En líneas generales, esta relación conceptual entre AT y NT no existe con respecto al Corán. Sin embargo, la tradición islámica habría utilizado específicamente unos pocos pasajes del AT que se entendían como alusiones al advenimiento del Islam y del Profeta Mahoma.

24. H. LAZARUS-YAFEH, op. cit., p. 81.

25. Ibidem.

26. De hecho, sólo unos pocos autores tardíos, como es el caso en el siglo XI del cordobés Ibn Hazm, demostrarán en sus obras un conocimiento exhaustivo de la Biblia; véase H. LAZARUS-YAFEH, op. cit., pp. 76-77. 
apoya el recurso a dicho procedimiento exegético, ya que sólo un pasaje del mismo (21:105) es explicado por los exégetas musulmanes como una citación explícita de la Biblia (Salmos 37:29) ${ }^{27}$. No es extraño, por tanto, que muchos de los primeros autores musulmanes en argumentar sobre las "pruebas de la profecía" desde este dominio, como el mu'tazilí 'Abd al-Ŷabbār (m. 1025), empleen esta única referencia coránica como mención directa de la misión mahomética y del advenimiento del Islam por su precedente bíblico ${ }^{28}$.

Sin embargo, parece que para el cadí 'Abd al-Ŷabbār el argumento bíblico no constituía en este periodo ninguna clase de innovación. Con el surgimiento del Islam y la declaración profética de Mahoma, y a partir del rechazo que ésta produjo en judíos y cristianos, los rasgos que distinguían al verdadero profeta de los impostores se convirtieron en tema clave. Y aunque desde el siglo IX encontramos este tópico ya elaborado por musulmanes, judíos y cristianos al mismo tiempo, es posible asegurar que fue el Islam el primer impulsor de esta corriente de "significación profética" en respuesta a la incredulidad de cristianos y judíos frente al nuevo mensaje ${ }^{29}$. Según 'Abd al-Ŷabbār, la identificación profética de Mahoma provocó la refutación por parte de judíos y cristianos de las cualidades que lo permitían, lo que forzó a los musulmanes a establecer un sistema de vindicación del carácter profético de Mahoma, señalando la existencia temprana de autores musulmanes que habrían compuesto libros específicos (aparentemente perdidos) sobre tales profecías ${ }^{30}$. No obstante, ya a principios del siglo VIII, Juan Damasceno (m. 724) desafiaba a los musulmanes a que probaran la revelación de Mahoma, al tiempo que rechazaba sus cualidades proféticas ${ }^{31}$, para lo que en ocasiones empleaba textos de la tradición islámica sobre la vida del Profeta (Sìra), como la conocida historia del monje cristiano Bahīrà ${ }^{32}$. Más aún, el autor mu'tazilí admite que el debate sobre las referencias bíblicas a Mahoma comienza a gestarse ya en vida del propio Profeta, cuyos principales sustentadores serían precisamente los primeros judíos islamizados, citando explícitamente a uno de todos ellos: el medinés 'Abd Allāh b. Salām ${ }^{33}$.

27. Sobre este aspecto véase el estudio clásico de M.J. GoeJE, «Quotations from the Bible in the Qoran and the Traditions», Semitic Studies in Memory of Rv. Alexander Kohut, Berlín, 1897, pp. 179-185.

28. H. LAZARUS-YAFEH, op. cit., p. 77.

29. S. StROUMSA, op. cit., p. 105; H. LAZARUS-YAFEH, op. cit., p. 79.

30. Cfr. 'Abd AL-ŶABBĀR, Tateitt dalā'il an-nubuwwwa, 2 vols., Beirut, 1966, vol. 2, pp. 252-253.

31. Véase a este respecto D.J. SAHAS, John of Damascus on Islam: The Heresey of the Ishmaelites, Leiden, 1972, p. 79 y ss.; igualmente, para la cita concreta en la obra del Damasceno (De haer., 101), F.H. CHASE, Saint John of Damascus: Writings, Washington, 1981, pp. 153-154.

32. Véase A.Th. KHoury, Polémique byzantine contre l'Islam (VIIIe-XIIIe s.), Leiden, 1972, p. 77; e igualmente D.J. SAHAS, op. cit., pp. 73-74.

33. Cfr. 'Abd AL-Ŷ̀BBĀR, op. cit., vol. 2, p. 252. 


\section{HACIA UN CONTORNO IDEOLÓGICO: LA SİRA DE IBN ISHĀQ Y 'ABd AllāH B. SALĀM}

La temprana adscripción del debate sobre las "señales de la profecía" en Mahoma a los primeros tiempos del Islam por 'Abd al-Ŷabbār encuentra su piedra angular en la primitiva Sìra de Muhammad Ibn Isḥāq (m. 768), conservada parcialmente en la recensión expurgada de Ibn Hišām (m. 923). En ella, una larga sección aparece dedicada a "cómo algunos adivinos (kuhhān), sabios judíos ( $a h b \bar{a} r$ ) y monjes cristianos predicen su venida (i.e. de Mahoma) $)^{\prime 34}$. Por primera vez en la tradición árabe se desarrolla el topos de la presencia de la descripción de Mahoma en los Libros Sagrados de judíos y cristianos. La sección incluye igualmente el famoso versículo del Evangelio de Juan sobre el paráclito, y es Ibn Ishāāq precisamente el primero que trae la noticia de su identificación con el Profeta, inaugurando uno de los argumentos centrales de la polémica islamocristiana ${ }^{35}$ y clave en el desarrollo literario del motivo de la conversión de cristianos al Islam durante toda la Edad Media ${ }^{36}$.

La Sìra de Ibn Ishāq dedica una atención singular a la figura de 'Abd Allāh b. Salām, identificándole precisamente como uno esos doctores judíos (habr) que dicen hallar en sus Escrituras los signos que identifican a Mahoma como profeta y que vaticinan el momento de su venida ${ }^{37}$. La historia de su conversión al Islam se incluye, igualmente, en la Vida del Profeta $(\operatorname{Sir} r a)^{38}$, al tiempo que sus virtudes morales (fad a'́il) son recogidas por los más importantes compiladores de sunna ${ }^{39}$, fortuna que contrasta con las escasas tradiciones del Islam primitivo que se hacen remontar al propio 'Abd Allāh como tradicionista $^{40}$, contando con la excepción del texto de Buluqiya. Sin embargo, no es

34. Véase Ibn HišĀM, Sìrat an-nabī, 4 vols., El Cairo, 1963, vol. 1, p. 132.

35. Véase S.H. GRIFFITH, «The Gospel, the Qur'ān, and the Presentation of Jesus in al-Ya'qūbì's Ta'rīkh», en J.C. ReEves (ed.), Bible and Qur'ān: Essays in Scriptural Intertextuality, Atlanta, 2003, pp. 133-160; $y$ «Arguing from Scripture: The Bible in the Christian/Muslim Encounter in the Middle Ages», en T.J. HefFernan y T.E. Burman (eds.), Scripture and Pluralism: Reading the Bible in the Religiously Plural Worlds of the Middle Ages and Renaissance, Leiden, 2005, pp. 29-58.

36. Véase M. de EPAlZA, Fray Anselm Turmeda (Abdallāh al-Tarŷumān) y su polémica islamo-cristiana. Edición, traducción y estudio de la Tuhfa, Madrid, 1994, 2a ed., pp. 34-36.

37. Cfr. Ibn HišĀM, op. cit., vol. 2, p. 360.

38. Para la historia de su conversión y su adscripción a la primitiva Sìra de Ibn Ishạāq véase Ibn KAĪīr, al-Bidāya wa-n-nihāya, 14 vols., Beirut, s.f., vol. 3, pp. 211-212; Ibn HAYŶAR, al-Ișāba fì tamyīz

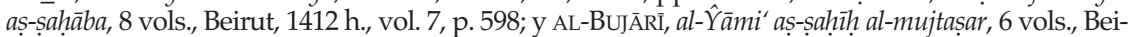
rut, 1987, vol. 3, p. 1211 y vol. 4, p. 1423. Véase igualmente Ibn HIšÀM, op. cit., vol. 2, p. 361 y ss.

39. Véase MusLim, Șahīh 5 vols., Beirut, s.f., vol. 4, p. 1929 y ss.

40. Véase G.F. PIJPER, Het Boek der Dui end Vragen, Leiden, 1924; J. HorowITZ, «Review of Pijper, G.F., Het Boek der Dui end Vragen», Der Islam, 16 (1927), pp. 296-298; M. FurATI, Quarante Questions addressées par les Docteurs juifs au prophète Mahomet, Viena, 1851, apud J. HeIn, Das Buch der Vier ig Fragen, Leiden, 1960; G. VAJDA, «Juifs et musulmans selon le hadiț», Journal Asiatique (1937), 99, n.1. 
de extrañar que su figura, como la de Ka'b al-Aḥbār, fuera empleada por los musulmanes para dar voz a otras supuestas tradiciones judías que, como en el caso de Buluqiya, profetizaban la misión de Mahoma ${ }^{41}$.

El caso del judío yemenita Ka'b al-Aḥbār, idéntico al de 'Abd Allāh, es también recogido tempranamente por Ibn Sa'd (m. 845) en la sección de su célebre Tabaqāt titulada "La descripción (șifa) del Mensajero de Dios en la Torá y en el Evangelio" ${ }^{42}$, en donde $\mathrm{Ka} \mathrm{b}^{\prime} \mathrm{b}$, citando un fragmento de la Torá, presenta lo que a su parecer es una descripción de Mahoma, pasaje que guarda cierta similitud con Isaías 42:23. La propia terminología empleada en la Sīra es sumamente cuidadosa en la diferenciación de este tipo de representantes judíos, quienes auspiciaban la nueva profecía, de la casta de los rabinos $(r a b b \bar{a} n)^{44}$, siendo igualmente muy numerosas las anécdotas de estos aḥbār y sus predicciones proféticas en las obras de dalä'il an-nubuwwa ${ }^{45}$. Pero también la literatura tradicional dibuja un perfil de estos doctores judíos y su importancia como lectores de las Escrituras. Así, en el relato de Buluqiya, el judío 'Affān es presentado como $h a b r^{46}$, y es él quien confirma la profecía hallada en los legajos de su padre:

“No podrías alcanzar el tiempo que ha de venir aqueste annabī [=profeta] Muhammad, șalà Allāhu 'alayhi wa-sallam [=¡Dios le bendiga y salve!], y su alumma [=comunidad], que ese annabī y su alumma según se liye por la Escribtura no ha de venir daquí a el tiempo zaguero, porque él es el zaguero de los annabies [=profetas], que después dél no verná annabī porque él es sillo de todos los annabīes y el zaguero de los mensajeros de Allāh el Noble y el Todopoderoso" ${ }^{\prime 7}$.

La noción de "sello de la profecía" (jātim an-nubuwwwa) que aparece en el texto supone un desarrollo del dogma de la predestinación profética con que el Corán privilegia a Mahoma ${ }^{48}$, posee su precedente en el Libro de Da-

41. J. Horowitz, «Abd Allāh b. Salām», EI2, I, 53; «Abd Allāh ibn Salām», Encyclopaedia Judaica, 1970, I, pp. 53-54; M. STEINSCHNEIDER, Polemische und apologetische Literatur in arabische Sprache zwischen Muslimen, Christen und Juden, Leipzig, 1877, pp. 110-115.

42. Véase Ibn SA`D, Tabaqāt al-kubrà, 8 vols., Beirut, 1960, vol. 1, pp. 360-363.

43. Para un estudio detallado de la predicción de Ka'b y su referente bíblico véase J.D. McAuLIFFE, «The Prediction and Prefiguration of Muhammad», en J.C. ReEves (ed.), Bible and Qur'ān: Essays in Scriptural Intertextuality, pp. 118-119.

44. También el Corán muestra una clara distinción entre las dos castas judías (cfr. 5:46 y 5:65).

45. Cfr. AL-IșBAHĀNī, Kitāb dalā'il an-nubuwwwa, Riyad, 1409 h., pp. 79, 80, 83, 156 et passim.

46. Cfr. AT-TA'LAB̄̄, Qiṣaṣ al-anbiyā', p. 478, donde dice: fa-atà [Bulūqiyā] Bayt al-Maqdis wa-kāna bihā habr min ahbārihim yusammà 'Affān, el recensionista morisco sólo afirma: "Depués vino Buluqiya a la casa de Baytu al-Maqdis y halló en ella un hombre [sic] que le dicían por nombre 'Affān" (fol. 86r).

47. Ms. Junta VIII, fols. 86v-87r. Remarco con negrita.

48. Véase Corán 33:40: "Mahoma no es el padre de ninguno de vuestros hombres, sino que es el Mensajero de Dios y el sello de los profetas (jātim an-nabī'īn)". 
niel $^{49}$ y puede guardar relación con estos $a h ̧ b \bar{a} r^{50}$. El más temprano testimonio de estos desarrollos literarios lo encontramos igualmente en la Sìra de Ibn Ishāà, en lo que tal vez constituye la narración fundacional de la profecía en Mahoma: el reconocimiento por el monje cristiano Bahīrà del "sello" o marca física que identifica al joven árabe, durante uno de sus viajes a Siria, como sucesor de los profetas del Pueblo de Israel ${ }^{51}$. Ciertamente, la etimología del nombre del citado monje se remite al siríaco b’ḥi $r \bar{a}$ ("el escogido", de baḥr) y ha de relacionarse con el hebreo haber y con su derivado árabe.

Es necesario entender el valor genesiaco de la propia doctrina islámica para conocer igualmente el verdadero valor de las historias de estos aḥbār judíos o cristianos en la literatura de tradición heredada por los moriscos. De acuerdo con la Sìra, la confirmación de Mahoma como profeta de los gentiles (an-nabì al-umm $\bar{\imath})^{52}$ por obra y gracia de Waraqa b. Nawfal, un cristiano versado en las Escrituras y primo de su mujer Jadîya, resultaba la clave para que el propio Profeta entendiera el significado y la naturaleza de sus primeras revelaciones $^{53}$. Según le apercibe Waraqa a Mahoma, no había duda de que el ángel Gabriel (an-nāmūs al-akbar) se le había presentado en el monte Hira con los mismos

49. La noción mesiánica de "sello" (hebr. jotam) aparece por vez primera en Daniel 9:24 y se desarrolla con rasgos escatológicos en Hageo 2:23 cuando Dios declara a Zorobabel: "Te tomaré a ti [...] y te pondré como anillo a sellar porque yo te he escogido". Es interesante señalar que la leyenda islámica de Daniel aparece ligada a las figuras de 'Abd Allāh b. Salām y Ka'b al-Aḥbār, y concierne a ese carácter de predicción escatológica o profética en torno al hallazgo de un anillo y un Libro ocultos, véase S. GROTZFELD, «Dāniyāl in der arabischen Legende», en W. Fischer (ed.), Festgabe für Hans Wehr, Wiesbaden, 1969, p. 84. Igualmente, la noción de "sellar" el Libro, con el sentido de completar la profecía y su mensaje definitivo, se expresa en Daniel 12:4 en las palabras de Gabriel: "Cierra las palabras y sella el Libro hasta el final de los tiempos", y, como ya señaló Casanova, se constituye como principio básico de la profecía islámica, al equipararse la expresión "sello de la profecía" con la idea de Mahoma como "mensajero del final de los tiempos" (rasūl ājir az-zamān), cfr. P. CASANOVA, Mohamed et la fin du monde, París, 1911, pp. 8, 18, 207-213, 228.

50. La concepción escatológica del Libro de Daniel hubo de ser introducida en la Península Arábiga por las sectas judías anti-rabínicas y maniqueas, especialmente asentadas en Yemen, como los $a b n \bar{a}^{\prime}$ de origen persa. Probablemente, el título de habr respondía al desempeño sacerdotal relacionado con el rito zadokita de estos grupos confesionales que, al igual que los esenios y a diferencia de los rabinitas, rechazaban la legitimidad de una "Torá oral"; el propio Ka'b pudo pertenecer a una de estas castas y ostentar el cargo de habr (de ahí que conservara el apelativo al-Aḥbār, según una referencia de al-Mas'ūdī), cfr. S.A. ARJOMAND, «Messianism, Millennialism and Revolution in Early Islamic History», en A. AMANAT y M.T. BERNHARDSSON (eds.), Imagining the End. Vision of Apocalypse from the Ancient Middle East to Modern America, Londres, 2002, pp. 110-111.

51. Véase Ibn HIŠĀM, op. cit., vol. 1, p. 116 y ss.

52. Con el sentido de quienes no poseían todavía la Escritura, esto es, la Torá o el Evangelio.

53. S.A. ARJOMAND, op. cit., p. 111; R. BlACHÈRE, Le problème de Mahomet: essai de biographie critique du fondateur de l'islam, París, 1952, p. 41; Ch. RABIN, «Islam and the Qumran Sect», Qumran Studies, Londres, 1957, pp. 122-23. Cfr. Ibn HIŠĀM, op. cit., vol. 1, pp. 102, 123, 146 et passim. 
estímulos que ante Moisés en el Sinaí ${ }^{4}$. De este modo Ibn Ishạā relaciona la buena nueva del anuncio de Mahoma por los sabios judíos y cristianos con la propia tradición profética del Pueblo Judío, tal y como ya ha observado Jacob Lessner, en un flujo de lecturas interrelacionadas, por un lado, con lo expresado en Corán 3:80 ("Y ten presente el compromiso que Allāh pidió a los profetas: os damos parte de un Libro y de una Sabiduría, luego vendrá a vosotros un mensajero que confirmará lo que tenéis; en él habréis de creer y le habréis de ayudar") y, por otro, con las tradiciones conocidas como isrā'îliyyāt, las historias islámicas sobre los profetas del Pueblo de Israel ${ }^{55}$.

No obstante, a partir de la cita de Corán 3:80, la tradición musulmana revisa la personalidad de los profetas judíos, especialmente como portadores de un mensaje divino (encarnado en la Torá, los Salmos y el Evangelio) derivado del Libro Eterno -la propia palabra de Dios-, que es el modelo prístino del Corán. Asimismo, si las Sagradas Escrituras se entienden, desde este punto de vista, como las sucesivas emanaciones de la Palabra Eterna en contextos y necesidades distintas, igualmente los profetas transmisores de dicha Palabra se presentan en grado a tales contextos, pero también en relación al valor perfectivo de la "restauración islámica" y por tanto del profeta portador del verbo "perfectivo" (Mahoma como "sello de la profecía") $)^{56}$ en calidad de precursores ${ }^{57}$. Y entiéndase "restauración" porque el propio texto del Corán asume para sí la idea de hanífismo, esto es, la de un modelo primigenio de fe en Dios único ${ }^{58}$, desde la perspectiva de entender las revelaciones desde un patrón común, siguiendo con lo expresado en la azora tercera: "Abraham no era ni judío ni cristiano, sino hanīf y musulmán” (3:66). Según explica la Sīra de Ibn Ishāà, un día el Profeta acudió al Bayt Midrās e invocó a los judíos allí presentes a que abrazaran el Islam. A la pregunta de que definiera la naturaleza de su credo, Ma-

54. Cfr. Ibn HišĀM, op. cit., vol. 1, pp. 156-57. Para su adscripción a Ibn Ishạāq véase aṭ-Tabarī, Ta'rīj al-umam wa-l-mulūk, 5 vols., Beirut, 1407 h., vol. 1, p. 533; y al-Hākim an-Nisābùīi, al-Mustadrik 'alà aṣ-ṣaḥiḥinn, 4 vols., Beirut,1990, vol. 3, p. 202.

55. Véase J. LASSNER, «The Covenant of the Prophets: Muslim Texts, Jewish Subtexts», AJS Review, 15:2 (1990), p. 234 y ss.

56. W.A. BIJLEFELD, «A Prophet and More than a Prophet? Some Observations on the Qur'ānic Use of the Terms 'Prophet' and 'Apostle'», The Muslim World, 59 (1969), p. 4.

57. J.D. McAuliffe, op. cit., p. 109. Esta misma idea puede tener sus precedentes en los Padres de la Iglesia, pues, en un período temprano del Cristianismo, las corrientes cristológicas predominantes no consideraban a Jesús en función de profeta, precisamente porque el término "profeta" hacía referencia a una función secundaria precursora, siendo los profetas quienes anunciaban la efectiva venida de Jesús (Orígenes, Contra Celsus, 1,51); por tanto, los profetas prefiguraban a éste desde consideraciones tipológicas tomadas del AT (cfr. S. STROUMSA, op. cit., p. 105).

58. Para el concepto coránico de haniffiyya véase J. WAARENBURG, «Towards a Periodization of Earliest Islam According to Its Relations with other Religions», en R. PETERs (ed.), Proceedings of the 9th Congress of the «Union Européenne des Arabisants et Islamisants», Leiden, 1981, esp. pp. 317319 . 
homa contestó que la suya era "la religión de Abraham", a lo que aquellos replicaron que Abraham era judío; el Profeta les instó a que lo probaran con la Torá, pero se negaron y entonces Mahoma reveló la citada aleya del Corán ${ }^{59}$.

Igualmente, en otra tradición unos judíos de los Banū Qurayza preguntaron a Mahoma si ellos debían adorarle de la misma manera que los cristianos adoran a Jesús; el Profeta respondió negativamente, revelando de nuevo una aleya de la tercera azora del Corán: "No cabe en ningún ser humano a quien Allāh le ha dado el Libro, la Sabiduría y la Profecía, que diga a los hombres: Sed siervos míos en vez de siervos de Allāh; sino más bien: Sed maestros (rabbāni$y \bar{i} n=$ rabinos) puesto que conocéis el Libro y lo habéis estudiado" $(3: 78)^{60}$. No obstante, aț-Ṭabarī parte de la exégesis de esta aleya para explicar igualmente que la figura del habr se asimilaba en tiempos de Mahoma a la de doctor en ciencia religiosa ('ulama'), por debajo de los rabinos, quienes ostentaban el poder temporal y la guía espiritual del Pueblo Judío (fi dunyāhim wa-dīnihim), de ahí tal vez que al Islam primitivo le interesase más la figura de los aḥbār como adeptos musulmanes, al vislumbrar una evidente disputa de castas cuya coyuntura pretende revertir a su favor ${ }^{61}$.

De esta constante exhortación a resolver la oposición de judíos y cristianos a través de sus propias Escrituras se colige, desde el prisma teológico islámico, que no existe en teoría discrepancia entre lo contenido por las distintas revelaciones (Torá, Evangelio, Corán), porque todas ellas proceden de una misma fuente divina (según Corán 3:2). Así pues, las semejanzas entre el Corán y el resto de Libros han de entenderse como la efectiva revelación de un plan divino que señala a Mahoma con el sello de la profecía; sin embargo, las divergencias sólo pueden ser declaradas, siguiendo lo explicado en el Corán, como resultado de la corrupción (tahrîf) introducida en el proceso de recepción o transmisión de los textos de judíos y cristianos $\left(2: 75,4: 46,5: 13\right.$ y 5:41) ${ }^{62}$. Precisamente, la anunciación profética de Mahoma se corresponde con uno

59. Para la adscripción de este hadiz a Ibn Isḥāq véase Ibn KAT̄īr, op. cit., vol. 6, p. 175.

60. Cfr. AṬ-ṬABARĪ, Ŷāmi' al-bayān 'an ta'wīl āy al-qur'ān, 12 vols., Beirut, 1405 h., vol. 3, pp. 326-327.

61. Para comprender el espíritu mesiánico surgido de entre las tribus judías de Arabia en el periodo al que aludimos véase G.D. NEWBY, «Text and Territory: Jewish-Muslim Relations 632$750 \mathrm{CE}$, en B. HARY et al. (eds.), Judaism and Islam: boundaries, communication and interaction: essays in honor of William M. Brinner, Leiden/Boston, 2000, pp. 83-96. Véase otra explicación sobre la figura de estos ahbōr en nota 50.

62. Véase M. PerlmanN, «Medieval Polemics Between Islam and Judaism», en S.D. GoITEIN (ed.), Religion in a Religious Age, Cambridge, 1974, pp. 103-139; H. LAZARUS-YAFEH, op. cit., pp. 26-29 y 58-72; para una clasificación textual del desarrollo del concepto véase J.M. GAUDEUL y R. CASPAR, «Textes de la tradition musulmane concernant le tahrīf (falsification) des Éscritures», Islamochristiana, 6 (1980), pp. 61-104; J. SADAN, «Some Literary Problems Concerning Judaism and Jewry in Medieval Arabic Sources», en M. SHARON (ed.), Studies in Islamic History and Civilization in Honour of Professor David Aylon, Leiden/Jerusalén, 1984, p. 371. 
de los argumentos fundamentales que desarrolla la doctrina islámica de tahrî̄f en su vertiente polemista ${ }^{63}$.

\section{BULUQIYA Y LA IMPRONTA DE LOS CONVERSOS DE LAS GENTES DEL LIBRO}

La figura de estos primeros musulmanes de las Gentes del Libro constituye el modelo arquetípico de conversión al Islam. No obstante, el episodio de la conversión de 'Abd Allāh b. Salām ha sido concebido como el acontecimiento definitivo que convenció a Mahoma de que él era el profeta esperado por los judíos que citaban continuamente para oponerse a los idólatras mecanos $^{64}$. Téngase en cuenta que, de acuerdo con el pensamiento islámico, estos primeros conversos constituyen el importante eslabón de individuos que habría restituido el auténtico vínculo con el judaísmo primigenio (i.e. la idea de han̄̄fismo) supuestamente desvirtuado ${ }^{65}$. Por ello renuncian a una Ley Mosaica abrogada (mansīj) por una actualización de la Ley de Dios significada en el Corán, pero el más extenso contorno de su pasado sagrado pervive, en las tradiciones islámicas a las que se les liga, especialmente mediante la veneración de las figuras o personae que lo encarnan (isrā'iliyyât $)^{66}$.

No en otro sentido habría que ponderar las noticias que afirman que 'Abd Allāh se proclamaba a sí mismo descendiente del profeta José ${ }^{67}$, testimonio que, tal vez, nos esté revelando que se trataba de un judío de origen egipcio ${ }^{68}$, circunstancia que puede haber inspirado algunos motivos folclóricos de la leyenda de Buluqiya. No obstante, el pasaje de la isla habitada por Tamali, la reina de las serpientes del infierno, alude a una antigua historia del Egipto Antiguo, conocida como "La isla de Ka", compuesta en escritura hierática entre el 2000 y el 1800 a. C. durante el Imperio Medio, cuyo texto fue encontrado y descifrado por W. Golénisheff en $1905^{69}$. En este relato se narra el viaje maríti-

63. H. LAZARUS-YAFeH, op. cit., p. 20.

64. Véase I. di MATteO, La predicazione religiosa di Maometto e i suoi oppositori, Palermo, 1934, p. 242 y ss.; e igualmente M. de EpalzA, Fray Anselm Turmeda..., p. 29.

65. Véase J. LASSNER, op. cit., pp. 234-235.

66. Véase M.J. KISTER, «Haddithū 'an banīi isrā'îla wa-lā haraja. A Study of an early tradition», Israel Oriental Studies, 2 (1972), p. 222.

67. Cfr. Ibn HâYAar, op. cit., vol. 4, p. 118.

68. Repárese en la hipótesis de que la narración coránica sobre José pudiera haber recibido la influencia de los judíos alejandrinos de cultura helenizada, quienes habrían introducido el tema del amor platónico recogido en el texto coránico, véase A.L. de Prémare, Joseph et Muhammad. Le chapitre 12 du Coran, Aix-en Provence, 1989.

69. Véase J.M. Galán, Cuatro viajes en la literatura del Antiguo Egipto, Madrid, 1998, pp. 35-39. 
mo de un noble egipcio de la corte faraónica que naufraga y va a parar a una isla habitada por una serpiente gigante que, como la que sale al paso de Buluqiya, también posee el don del habla. No obstante, este antiquísimo relato egipcio, por su propia morfología, puede haber inspirado este primer acontecimiento del viaje de Buluqiya. Posiblemente fueron los judíos de este país los que recogieron esta historia antigua y ello explicaría que Buluqiya fuera además un cortesano israelita en Egipto ${ }^{70}$.

$\mathrm{Al}$ igual que en el relato de Buluqiya, la importancia de los episodios que narran la conversión de estos antiguos judíos radica en la identificación de los signos de la misión profética de Mahoma. Es el caso de las dos narraciones conservadas sobre la conversión de Ka'b al-Ahbāar ${ }^{71}$, al menos una de las cuales, la tradición transmitida por Hodayfe (=Hudayfa b. al-Yamān $\left.{ }^{72}\right)$, fue asimismo conocida y traducida al castellano por obra de moriscos ${ }^{73}$. En la primera de ellas, Ka'b relata al califa 'Umar que el origen de su conversión guardaba relación con la anécdota de que su padre le había hecho prometer que no leería ciertas escrituras -tomadas de la Torá- que había sellado y guardado celosamente; tras su muerte, $\mathrm{Ka}$ 'b accede a dichas escrituras y encuentra en ellas los nobles ordenamientos del Profeta Mahoma ${ }^{74}$, de la misma manera que acontece a Buluqiya en nuestra narración. La segunda historia nos narra su afanoso empeño por tratar de descubrir, durante varios años, por qué diez pasajes de la Torá habían sido borrados; al cabo de ese tiempo, un maestro judío (habr) le explica que aquellos se correspondían con diez versículos del Corán ${ }^{75}$. En una versión distinta a la traída por Hodayfe en el texto morisco, Ka'b descubre la verdad gracias a un monje cristiano, llamado curiosamente Bulujya ${ }^{76}$, referencia que deja al aire la significación del nombre de Buluqiya en el "ambiente" legendario de estos conversos de las Gentes del Libro. A consecuencia de ello, ambos, Ka'b y Bulujya, se convierten al Islam.

70. Véase M.J. RubieRA, «Un relat àrab de viatge al Més Enllà (Buluqiya), possible font de la Faula de Torroella», Estudis de llengua i literatura en honor de Joan Veny, I, Barcelona, 1997, pp. 78-79.

71. Ambos textos editados por M. PERLMAnN, «A legendary story of Ka'b al-Ahbār's conversion to Islam», en The Joshua Starr Memorial Volume, Nueva York, 1953, pp. 85-89; y «Another Kabu al-Ahbar story», The Jewish Quarterly Review, 14 (1954), pp. 48-58.

72. Sobre este personaje del Islam véase AL-BUJĀRI, op cit., vol. 3, p. 1390 y ss.

73. Se trata del «Alhadiç de Ca'bu-l-Ahbar de cuando se volvió muçlim y por qué causa», texto en caracteres latinos correspondiente al ms. BRAH 9393 (fols. 93-98), el cual tengo intención de editar y cuyo texto original árabe se podrá hallar en el ms. Cairo Fihrist VII-442 citado por M. PerlmanN, «Another Kabu al-Ahbar story»..., pp. 52-58 para el texto árabe.

74. Cfr. igualmente Ibn Sa'd, op cit., vol. 7, p. 445.

75. Véase M. PerLmanN, «Another Kabu al-Ahbar story»..., pp. 54-57.

76. Véase M. PERLMANN, «A legendary story of Ka'b al-Ahbār's...», esp. pp. 88-89; e igualmente, para la variante del nombre de Buluqiya, otro texto editado por J. MANN, «An Early Theological-Polemical Work», Hebrew Union College Annual, 12 (1937), p. 441. 
La inspiración del relato de Buluqiya en los dos hadices conservados sobre la conversión de $\mathrm{Ka}$ 'b es evidente ${ }^{77}$, como también lo es el concepto coránico del que parten ambas tradiciones, pues, dentro del contexto de acusación de "corrupción" (tahrîf) de las Sagradas Escrituras dirigida a los judíos, encontramos igualmente la variable conceptual de kitmān u "ocultamiento" de pasajes o palabras que, por obra humana, han sido substraídos de las originales Escrituras, motivo fundamental en el desarrollo de los textos de Ka'b y Buluqiya ${ }^{78}$.

Esta acusación de "ocultamiento" que desarrolla el Corán se presenta exclusivamente como una exhortación a las Gentes del Libro (3:71) y se le confiere un destacado rasgo punitivo relacionado con el fuego y el día del juicio (2:174): "Los que oculten lo que del Libro de Allāh se ha hecho descender [...] son los que venden la guía a cambio del extravío y el perdón a cambio del castigo. ¡Cómo se buscan el fuego!”. La misma referencia punitiva se argumenta en el relato de Buluqiya cuando, desvelado el hallazgo de la Torá, los súbditos de Israel solicitan al joven noble judío el castigo del fuego para su padre: “¡Ye Buluqiya!, tú eres [el] mayor de nosotros y nueso adelantado. Si tú has hallado eso en el tresoro de tu padre saquémoslo de su fuesa y quemémoslo en fuego porque nos encubrió la verdad"79.

La exégesis clásica ha explicado, sobre el mismo motivo coránico del "ocultamiento", que el versículo 5:43 del Corán descendió como consecuencia de un caso de adulterio entre los judíos de Jaybar que, no queriendo lapidar a los culpables, fueron a consultar el juicio de Mahoma, argumentado ante éste que entre ellos el castigo por adulterio consistía en unos pocos azotes y tiznar el rostro de los culpables, lo cual suponía una alteración del juicio original de la Torá, pues los judíos se la habían mostrado al Profeta ocultándole con la mano los pasajes relativos a dicho castigo; no es extraño que, en este contexto de confrontación y verificación de un escriturario, sea el ubicuo 'Abd Allāh b. Salām quien, según el desarrollo exegético del pasaje coránico, advierta a Mahoma del artificio de los judíos ${ }^{80}$. Sólo de este modo la revelación coránica, dirigida en sus orígenes a los beduinos paganos, adquiere tempranamente una evidente orientación confrontadora en oposición a judíos y cristianos ${ }^{81}$. Esta orientación y el carácter proselitista del Islam confieren, pues, a las historias que narran la conversión de las Gentes del Libro, con independencia de su vocación

77. Véase el juicio de S.M. WASSERSTROM, «Jewish Pseudepigrapha and Qiṣaṣ al-anbiya'»», en B. Hary et al. (eds.), Judaism and Islam, pp. 243-244.

78. El término kitmān aparece en el Corán con este significado en 2:42, 2:140, 2:146, 2:159, 2:174, $3: 71$ y 3:187; véase J.M. GAudeul y R. CASPAR, op. cit., pp. 62-63.

79. Ms. Junta VIII, fol. 83v.

80. Cfr. Ibn KAT̄īR, Tafsīr al-Qur'ān al-'Azìm, Beirut, 2000, p. 619; AL-BAGAWĪ, Ma'ālim at-tanzīl,

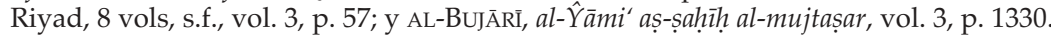

81. M. de Epalza, Fray Anselm Turmeda..., p. 29. 
historicista ('Abd Allāh b. Salām, Ka'b al-Aḥbār) o más o menos literaria (Buluqiya), un relieve teológico especial que dejará su impronta en los textos literarios sobre las conversiones del período tardomedieval (Turmeda) ${ }^{82}$.

Se debe consignar, por tanto, la significación que tiene la conversión y el relato de sus avatares en el contexto de una narración de base polemista. Toda la argumentación polémica está implícita en el propio motivo de la conversión, puesto que, según la percepción islámica, el converso de las Gentes del Libro puede establecer los argumentos de su apostasía precisamente a partir de las Escrituras que conoce por su anterior condición religiosa. Tomemos el ejemplo del relato aljamiado-morisco conocido como «Alhadiz de Sarŷil ibnu Sar$\hat{y} \bar{u} n{ }^{83}$ : esta tradición narra la historia de Sarŷîl, un monje cristiano procedente de Siria que, haciéndose acompañar de un séquito de fieles, se presenta ante Abū Bakr y sus compañeros para hallar explicación a una larga serie de preguntas que aclaren el significado de algunos pasajes oscuros tomados del Evangelio de sus antepasados, a cuya efectiva respuesta se condiciona en este caso la conversión del monje y sus correligionarios al Islam:

“¡Ye Abū Bakri!, yo he venido de tierras de Axxām (=Siria) con demandas contrarias que las he trobado (=hallado) en unas escribturas de mi padre y de mi agüelo; y si tú me las declaras así como son enta nosotros, sabremos que Muhammad es annabī (=profeta) y mensajero, y que el adīn (=religión) del alIslām es verdadero y todo lo otro no es nada" ${ }^{\prime 84}$.

En esta ocasión es 'Alī quien da cuenta no sólo de las demandas, sino también de la identidad del monje, que es presentada por éste bajo el mismo topos que describen las tradiciones de Buluqiya y Ka'b, el del texto oculto (kit$m \bar{a} n)$ en un legajo preservado en secreto, igualmente en una caja cerrada, pero trascendido para una figura venerable del Islam:

“¿Con qué has supido con mi nombre o quién te lo fizo a saber?, que nunca hubo ninguno que lo supiese jamás, que mi padre me nombró con este nombre lahora que caí del vientre de mi madre y escribiólo en una carta y púsola en una caxa, y puso en el prencipio de la carta 'fey homenaje (=juro) que ninguno que leyese aquella carta que no escubriese aqueste nombre'; y es que no conoce ninguno con mi nombre si no era mi padre; y lahora que él murió y plegué yo a ser hombre y enseñoreé los fechos después de él, abrí aquella escribtura y trobé en ella mi nombre, y helo encubierto de la gente $[\ldots]^{\prime \prime 85}$.

82. Ibídem. Agradezco al Prof. Epalza sus valiosas indicaciones sobre la importante influencia del hadiz de la conversión de 'Abd Allāh b. Salām en el texto de la Tuhfa de Anselm Turmeda. Se puede evidenciar igualmente el influjo de la legendaria conversión de Ka'b al-Ahbar en el relato de Turmeda (en ambos casos transcurrieron diez años de magisterio antes de que les fuera enseñada la verdad sagrada), cfr. Fray Anselm Turmeda, pp. 214 y 215 para el texto árabe.

83. El texto fue editado por O. HeGY, Cinco leyendas y otros relatos moriscos ( $m s .4953$ de la BNM), Madrid, 1981, pp. 73-85. El mismo texto se halla conservado en el ms. BRAH 9410 (T13), fols. 197v-207v.

84. Ms. BNM 4953, fol. 4r.

85. Ibídem, fol. $8 \mathrm{v}$. 
Tanto Sarŷîl ibnu Sarŷūn como Bahīrà -el personaje de la leyenda fundacional sobre el reconocimiento del signo profético de Mahoma- representan a monjes cristianos siríacos ${ }^{86}$ que sin duda venían a encarnar para los polemistas musulmanes de los siglos VIII y IX el paradigma de individuos que, según la cláusula observada en la Sìra de Ibn Isḥāq, reconocían la labor divina encomendada a Mahoma en contra de sus correligionarios melquitas, jacobitas o nestorianos ${ }^{87}$. Creo además poder establecer la hipótesis, que intentaré desarrollar en otro lugar, de que este texto hubiera formado parte de una primitiva recensión de la obra de Ibn Ishāàq, no sólo por el carácter apologético tan cercano al texto de la primera biografía del Profeta, sino también por dos referencias textuales que reconozco fundamentales: el relato de Sarŷil se remite a la autoridad de Silmān al-Fārisī, uno de los primeros conversos al Islam cuya figura ocupa un lugar muy destacado en la Sīr $a^{88}$; pero, además, en el rastreo de las fuentes originales árabes del texto aljamiado, he encontrado una recensión que aparece transmitida por el propio Ibn Ishāāq ${ }^{89}$. Por otro lado, el hecho de que sea 'Alī quien asuma la iniciativa de responder al monje más bien favorece nuestra hipótesis, puesto que algunos estudios ya han probado la más que recurrente presencia de 'Alī en la primitiva Sìra ${ }^{90}$, lo cual pudo constituir uno de los detonantes de su definitiva expurgación por Ibn Hišām en el ámbito sunní, y, en el caso concreto del hadiz de Sarŷil b. Sarŷūn, por no narrar además sus hechos en el tiempo de vida del Profeta.

La resolución de las "demandas contrarias" halladas en el Evangelio por el monje Sarŷil constituye, como se ha dicho, el factor que determina la conversión por el ejercicio del convencimiento. El esquema ideológico de estas "demandas", conocido en los textos de la tradición polemista musulmana ${ }^{91}$, plantea un concepto escatológico principal que requiere de refrendo, de ele-

86. Téngase en cuenta que a Bahīrà también se le conoce como Sarŷīs (Sergio) en algunas recensiones árabes de esta leyenda.

87. Véase J.P. MONFERrer SALA, «Un texto base polemista: la versión árabe andalusí de la leyenda del monje Baḥīrā incluida en el I'lām de al-Qurțubī», Qurțuba. Estudios Andalusíes, 4 (1999), p. 138.

88. Cfr. Ibn HıšĀM, op. cit., vol. 1, p. 139 ss.

89. He encontrado distintas versiones de esta tradición en AṬ-ṬABARSĪ, Kitāa al-ihtî̀āây, 2 vols., Nayaf, 1385 h., vol. 1, pp. 307-308; y AL-MAŶLISİ, Bihāar al-anwā̄r, 108 vols., Beirut, 1983, vol. 10, pp. 52-53, ambos textos de la tradición chií; y, seguramente más próximo a nuestro texto, en el manuscrito árabe Daiber Collection n ${ }^{\circ} 134$, fols. 24v-28v (inédito). La recensión transmitida por Ibn Ishāa se muestra, además, notablemente cercana a la versión aljamiada, cuyo texto lo he podido encontrar en un librito moderno de lógica deductiva: Sa'îd ibn 'Abd Allāh AL-HūsANī, Kitāb riyādat al-fikr, s.l., 1998 ( $2^{a}$ ed.), 23 ss., que, sin embargo, no indica su fuente clásica.

90. Véase U. RUBIN, «Prophets and Progenitors in the Early Shi'a Tradition», Jerusalem Studies in Arabic and Islam, 1 (1979), pp. 41-65.

91. Véase H. HIRSCHFELD, «Historical and Legendary Controversies between Mohammed and the Rabbis», The Jewish Quarterly Review, 10:1 (1897), pp. 100-116. 
mentos de confluencia que prueben por analogía la efectividad del concepto principal. Lógicamente, dicho refrendo transforma el simple concepto escatológico en signo profético a favor del Islam. En este sentido, estos relatos de conversiones de las Gentes del Libro adoptan, desde este punto de vista, una singular intertextualidad y cohesión en torno a sus figuraciones escatológicas que se plantean en el debate interreligioso. Así, por ejemplo, el relato de Buluqiya desarrolla en este sentido la figura de los ángeles responsables (al-muwakkalūn) de las fuerzas del universo ${ }^{92}$, precisamente cuando el viaje del israelita se torna escatológico, como compensatorio de la inadvertencia física del Profeta. Es el caso del ángel encargado de la sucesión de los días y las noches:

“Mi nombre es Hazel, y con poder de mi señor Allāh soy percurador (=encargado) de la claredad del día del mundo y de la escuredad de la noche. Y sepas, iye Buluqiya!, que si yo soltase mi mano enta el sol saliente no habría escuredad en la tierra ni en los cielos, que [todo sería] blanco para siempre. Y [si yo] soltase mi mano de la claredad del día se blanquearía los cielos y la tierra, y no habría escuredad nunca" ${ }^{93}$.

El texto árabe de Buluqiya traído por at- $\operatorname{Ta}^{\prime} l a b \bar{i}^{94}$ llama a este ángel Yūhāa yîl, cuyo origen se halla en el ángel Yaoel que aparece en el texto apócrifo del Apocalipsis de Abraham ${ }^{95}$, siendo éste igualmente el mismo referente angélico que emplea 'Alī en una de las resoluciones a las preguntas del monje cristiano Sarŷ̄il ibnu Sarŷūn:

“A cuanto lo que dīces en dónde es la noche cuando viene el día y en dónde es el día cuando viene la noche [...], viene otro almalake (=ángel), que su nombre es Šarahīl, y toma otra perla blanca y asómase con ella a sol saliente, y viene el día con su claredad y su resplandor y su señorío aqueste. Esto es feito cada día y cada noche, y Allāh es sabidor con aquello" ${ }^{\prime 6}$.

\section{BuluQiya y las “Demandas” de 'AbD AllāH B. SALĀM}

Este cariz de conversión condicionada a una serie de pruebas de valor exegético se presenta como parábola del concepto islámico polemista de tahrîf, en su variable conocida como taḥrîf al-ma'nà u "ofuscación de la interpreta-

92. Véase F. JADAANE, «Le place des Anges dans la théologie cosmique musulmane», Studia Islamica, 41 (1975), pp. 23-61; para la función angélica referida ibídem, p. 50.

93. Ms. Junta VIII, fol. $96 \mathrm{r}$.

94. AT-TÁLABĪ, op. cit., p. 481.

95. Cfr. Ap. Abh., 10. Para éste y otros referentes de los pseudoepígrafos que aparecen en el texto de Buluqiya véase S.M. WASSERSTROM, op. cit., p. 240 y ss.

96. Ms. BNM 4953, fols. 13v-14r. 
ción" de los textos sagrados por sus lectores judíos y cristianos ${ }^{97}$. El precedente inmediato del mismo se halla en el contexto de las tradiciones sobre la conversión de 'Abd Allāh b. Salām, quien aparece igualmente relacionado en la tradición árabe-islámica como interrogador del Profeta de los musulmanes en aspectos de escatología trascendente. Conocido como masá'il, este género de textos de la tradición musulmana en que Mahoma resuelve una serie de enigmas planteados por el judío como condición previa a su conversión se materializó definitivamente en forma de textos pseudo-enciclopédicos sobre cosmología y doxología islámicas ${ }^{98}$.

El origen de este subgénero de la tradición islámica se encuentra igualmente en la Sīra de Ibn Ishāāq, algunas de cuyas muestras, relacionadas con las encuestas dirigidas por grupos de judíos a Mahoma, podrían corroborar la extensión de la biografía del Profeta entre los moriscos ${ }^{99}$. No sólo se conservan en aljamiado las "demandas que hizo 'Abdu Allāh binu Salām"100, traducción aljamiada de las Masā'il 'Abd Allāh ibn Salām, y el ya citado "Alhadiz de Sarŷīl ibnu Sarŷūn», sino también varias tradiciones que responden a las "demandas que demandaron una compaña de judíos al annabī Muhammad"101, quienes examinan a Mahoma sobre algunos pasajes incógnitos de las revelaciones de Moisés que, según ellos mismos, "no sabe declararlas ninguno sino que sea almalake [=ángel] çercano o annabī [=profeta] enviado"102; o las "demandas

97. Los primeros autores de dalä'il an-nubuwwwa, como Ibn Qutayba, hablan de una distorsión de significado (tahrîf al-ma'nà) y nunca de una alteración física de los textos sagrados, refutando incluso la idea de una falsificación textual de las Escrituras, precisamente porque ello estaría privando al Islam de su principal signo de legitimidad, esto es, el hecho de que los textos bíblicos legitimaban la misión profética de Mahoma justamente en el estado en que se habían conservado.Véase C. ADANG, Muslim writers on Judaism and the Hebrew Bible. From Ibn Rabban to Ibn Hazm, Leiden, 1996, p. 225.

98. Véase A.M. PIETMONESE, «Le voyage de Mahomet au paradis et en enfer: une version persane du mi'rāj», en C. KAPPLER (ed.), Apocalypses et voyages dans l'au-delà, París, 1987, pp. 293-318, esp. 312; G.F. PIJPER, op. cit.; y J. KRITZECK, Peter the Venerable and Islam, Princeton, 1964. En 1876 (?) apareció editado en El Cairo un librito anónimo, a modo de catequesis, basado en las masā'il de 'Abd Allāh b. Salām, cuya introducción y algunos de los pasajes más significativos fueron editados por H. HIRSCHFELD, op. cit., p. 112 y ss. Curiosamente, algunos de sus pasajes coinciden con la versión aljamiado-morisca (vid. infra nota 116).

99. Véase a este respecto C. López-Morillas, Textos aljamiados sobre la vida de Mahoma: el profeta de los moriscos, Madrid, 1994, esp. 17-19; desgraciadamente López-Morillas no cita estos textos de "demandas" de la tradición aljamiado-morisca que, sin embargo, son parte esencial de la Sirra.

100. Conservado con faltas en el ms. Urrea de Jalón (fols. 170v-171r), edición de F. CORRIENTE, Relatos píos y profanos del ms. aljamiado de Urrea de Jalón, pról. M.J. Viguera, Zaragoza, 1990, pp. 256257.

101. Editado por M. SÁNCHEZ Álvarez, El manuscrito misceláneo 774 de la BNP (Leyendas, itinerarios de viajes, profecías sobre la destrucción de España y otros relatos moriscos), Madrid, pp. 156-170.

102. Ibidem, p. 156. 
que ficieron los diez sabios de los judíos al annabī Muhammad"103 y otras igualmente referidas por Saavedra ${ }^{104}$.

Tal y como se explicita en la Sīra de Ibn Ishạā, en orden a conocer el carácter de la declaración profética de Mahoma, sus enemigos mequíes mandan a dos de sus emisarios (an-Naḍr b. al-Hārit y 'Uqba b. Abī Mu'ît) a consultar a un grupo de $a h b \bar{a} r$ mediníes, teniéndoles por eminentes conocedores de la Antiguas Escrituras; éstos proponen tres preguntas que han de ser formuladas al Profeta para determinar si es verdaderamente el enviado de Dios. Tras el regreso de los dos mequíes, una comitiva se presenta ante Mahoma con las tres cuestiones, que en un primer momento no sabe resolver; pero al cabo de varios días es inspirado por el ángel Gabriel y responde a las preguntas, cuya resolución es hecha saber a los sabios judíos, quienes acaban reconociendo sus signos como verdadero profeta de Dios y su descripción en la Torá ${ }^{105}$.

El relato de Buluqiya comparte, no obstante, un cierto substrato filogenético con estas tradiciones de masā'il. En primer lugar, porque la primera cita textual de Buluqiya que se conserva aparece precisamente en una de estas ma$s \bar{a}^{\prime} i l$ en persa, que es supuestamente traducción de un texto de at-Tabarī (m. 923). Se trata de la adaptación realizada por al-Bal'amī (m. 974) del Ta'rij ar-rusul $w a-l-m u l \bar{u} k$, si bien el texto al que aludimos no se ha conservado en la obra del historiador árabe. Dicha mención se reduce a una anécdota relatada por Mahoma como contestación a ciertas cuestiones planteadas por un grupo de judíos que se referían específicamente a la tumba de Salomón. De este modo, el autor persa pone en boca del Profeta la siguiente responsa:

"La tumba de mi hermano Salomón se halla en medio de un piélago, el cual forma parte del Gran Mar, en un palacio excavado en la roca. Dicho palacio guarda un trono, sobre el que ha sido instalado Salomón en la misma actitud que tenía durante su reinado, con el anillo real luciendo en su dedo, de tal modo que se diría que Salomón permanece todavía con vida. En esta isla hay doce guardianes que velan día y noche a Salomón. Ninguna criatura humana ha podido llegar jamás al lugar donde se encuentra la tumba, porque para alcanzar el lugar donde reposa este príncipe hay un recorrido de dos meses por mar. Se cuenta que tras la muerte de Salomón ninguna criatura ha llegado hasta su tumba, excepto dos personas: una era Affān y la otra Buluqiya"106.

103. Véase el ms. aljamiado BRAH 9415 (T19), fols. 157r-168v, editado por N. MARTínEZ DE CASTILLA, Edición, estudio y glosario del manuscrito aljamiado T19 de la Real Academia de la Historia, Madrid, Universidad Complutense, 2004 (tesis doctoral inédita).

104. Véase E. SAAvedra, Discursos leídos ante la Real Academia Española, Madrid, 1878, LXIX, nº 9, LX, $\mathrm{n}^{\mathrm{o}} 7$, LXIII, $\mathrm{n}^{\circ} 3, \mathrm{LXXXVI,} \mathrm{n}^{\mathrm{o}} 25$ y XCIII, $\mathrm{n}^{\circ} 24$.

105. Cfr. Ibn HišĀM, op. cit., vol. 1, p. 194 y ss.; y también en al-Iṣbahānī, Dalā'il an-nubuwwa, p. 216; para la adscripción del hadiz original a Ibn Ishạa véase al-BAYHAQĪ, Sunan al-Bayhaqī alkubrà, 10 vols., Meca, 1994, vol. 9, p. 64; y AṬ-ṬABARİ, op. cit., vol. 8, p. 174.

106. Traducción de H. Zotenberg, De la Création à David: extrait de la Chronique de Tabari, París, 1984, p. 64 (reedic. vol. 1 de Chronique de Tabari traduite sur la version persane d'Abou-Ali Mohammed Bel'ami, 4 vols., París, 1867-1874). 
En segundo lugar, el viaje al más allá de Buluqiya en busca de los signos del Islam, como se ha advertido anteriormente, constituye una plétora de figuras de tipo escatológico que van apareciendo bajo el modelo de preguntas y respuestas entre el joven israelita y distintos seres angélicos. Algunas de estas representaciones escatológicas están presentes también en las tradiciones conservadas sobre las preguntas de 'Abd Allāh b. Salām a Mahoma, como es el caso del pez Leviatán que sirve de alimento en el paraíso, según un fragmento de las masā'il Ibn Salām recogido por al-Bujārī:

“Cuando ['Abd Allāh] supo que Mahoma estaba en Medina se presentó ante él y le dijo: quiero formularte tres preguntas a las que solamente un profeta podría responder: ¿cuáles serán las condiciones de la Hora del Juicio? Un fuego que acabará con la Humanidad de este a oeste -contestó Mahoma; ¿y cuál es el primer alimento de los habitantes del paraíso? El hígado de cierto pez -respondió Mahoma; ¿y qué hace que un hijo se parezca más a su padre o a su madre? Cuando es mayor la secreción del hombre que la de la mujer, el niño sale a él, y cuando es mayor la de la mujer que la del hombre, entonces sale a ella ${ }^{107}$-contestó Mahoma. Luego exclamó ‘Abd Allāh: ¡No hay más Dios sino Allāh y tú eres su mensajero!"108.

En el caso de la historia de Buluqiya la figura del alimento escatológico se presenta de forma novelada, en el diálogo entre el judío y estos mismos peces del paraíso:

"Y díxoles Buluqiya: ¡Ye peces!, yo estoy con mucha gana de comer y beber, y tengo mucha sed en esta mar salada. ¿Habría en vosotros que me diésedes a comer alguna cosa?". Y respondiéronle ellos: «de ellos, con poder de Allāh, aquél que suelta las lenguas y las traba cuando Él quiere» [...]"109.

El origen de este tópico se halla en la literatura rabínica del midrás a partir de la cita bíblica de Job, 40:15 sobre el Leviatán o Bahamut ${ }^{110}$, el animal o pez que sirve de sustento a los piadosos en el paraíso ${ }^{111}$. No obstante, en la tradición

107. El mismo pasaje se ha conservado también en la tradición aljamiada de las "demandas" de 'Abd Allāh b. Salām (Ms. Urrea de Jalón, fol. 170v, F. CoRRIENTE, op. cit., p. 257):

"A cuanto el hijo si resemella [=asemeja] o parece a su 'amis [=familia paterna] o jālis [=materna], pues cuando es venciente [=prevaleciente] que son más las aguas y gota del hombre que la gota de la mujer, parece el hijo a su 'ammi; y cuando vience la gota de la mujer, parece el hijo al jāli".

Apréciense evidentes calcos semánticos del árabe con respecto al texto de al-Bujārī: "venciente, vience" (donde en ár. dice saqaba) y "aguas" (con el sentido de "esperma", donde el texto ár. dice $\left.m \bar{a}^{\prime}\right)$. El texto puede hallarse igualmente en al-Ișbahānī, Dală'il an-nubuwwwa, p. 211.

108. AL-BujĀRĪ, op. cit., vol. 3, p. 1433. Traducción mía. Remarco en negrita.

109. Ms. Junta VIII, fol. 103r. Remarco en negrita.

110. Cfr. Midrás Tanhuma Shemini, xiii (apud H. HiRSCHFELD, op. cit., p. 111, n. 3).

111. Sobre las divergencias exegéticas que hablan del tipo de bestia de que se trata, mamífero terrestre o pez, véase J.V. KinNIER WiLsON, «A Return to the Problems of Behemoth and Leviathan», Vetus Testamentum, 25:1 (1975), pp. 1-14; para el mito de Leviatán/Bahamut en los 
islámica, la imagen del Leviatán/Bahamut aparece también asociada a la visión cosmogónica del "asiento del mundo", motivo escatológico ${ }^{112}$ que, de nuevo, reaparece tanto en la tradición de Buluqiya como en las "demandas" de "Abd Allāh que se preservan en aljamiado:

“¡Ye Buluqiya!, el estado d-este monte es sobre los cuernos de un buey ${ }^{113}$, y aquel buey está su cabeza en sol saliente y su coda a sol poniente. Y él asajuda (=se arrodilla) de enta ada Allāh, el Noble y Alto, sobre una peña blanca"114.

Del mismo modo responde Mahoma a 'Abd Allāh b. Salām, en la tradición morisca, a su "demanda" sobre el "asiento del mundo":

"A cuanto el asiento de las tierras siete[s], pues ellas están asentadas sobre las cuestas de un pez ${ }^{115}$, y aquel pez está sobre una peña, y la peña está sobre un cuello de un almalak (=ángel), y no habe debaxo dél sino la escuridad"116.

Más aún, este género de textos ha dejado rastros todavía más sutiles en el relato de Buluqiya que sobrepasan los límites de la literatura de tradición islámica. Las masā'il de 'Abd Allāh b. Salām establecen vínculos conceptuales con un texto contemporáneo judío sobre este mismo género de cuestiones, el conocido como Alfabeto de Ben Sira ${ }^{117}$. Hay motivos suficientes para pensar que esta obra era muy conocida entre los judíos contemporáneos de Mahoma, pues se conserva un jabar autorizado por Ka'b al-Ahbār que supone una amplificación de un antiguo proverbio que el Talmud (Sanh. $100 \mathrm{~b}^{118}$ ) atribuye a una supuesta primitiva recensión de la obra de Ben Sira ${ }^{119}$. Ben Sira es identificado en su

textos agádicos véase L. GINZBERG, The Legends of the Jews, 6 vols., Philadelphia, esp. vol. 5, pp. 41, 44-46; y B. HeLleR, "Ginzberg's Legends of the Jews», The Jewish Quarterly Review, 24:1 (1933), pp. 51-66; y 24:4 (1934), pp. 393-418.

112. El origen de este topos puede hallarse igualmente en el Apocalipsis de Abraham, 21:4, véase S.M. WASSERSTROM, op. cit., pp. 241 y 255.

113. Sabemos por el relato árabe de at- $\underline{-} a^{\prime} l a b i ̄$ que se trata del buey o toro (tawr) Bahamūt, $c f r$. Qișaș al-anbiya', p. 483.

114. Ms. Junta VIII, fol. 101v.

115. Como se observará, la tradición islámica persiste en las divergencias exegéticas del judaísmo sobre el tipo de animal de que se trata, toro o pez (véase supra notas 111 y 113).

116. Ms. Urrea de Jalón, fol. 170v, apud F. CORRIENTE, op. cit., pp. 256-257; el texto original de este pasaje puede hallarse en la edición cairota de 1876 de las Masā' $̂$ l de 'Abd Allāh b. Salām (vid. supra nota 98), en donde se cita explícitamente el nombre del pez (Bahamūt), cfr. la edición de este texto en H. HiRSCHFELD, op. cit., p. 116.

117. Véase S.M. WASSERSTROM, op. cit., p. 245.

118. Sigo por la versión inglesa de Soncino Babylonian Talmud, 7 vols., Londres, 1935-48, vol. 1 (Sanhedrin), p. 681.

119. Véase E. MARMORSTEIN, «A note on the Alphabet of Ben Sira», The Jewish Quarterly Review, 41/3 (1951), pp. 303-306. Según este autor, la obra pudo ser conocida genéricamente en el Creciente Fértil como "Libro de Ben Sira". 
propia obra como hijo de Jeremías ben Hilqiya y relacionado con la casta sacerdotal $^{120}$. Hilqiya, supuesto abuelo de Ben Sira, vivió en tiempos del rey judío Josías, pues fue el sumo sacerdote encargado por éste de la reparación de la mansión de Yahvé, en el curso de la cual Hilqiya descubrió el Libro de la Ley en el Templo (Reyes 2, 22,1-13). Se trata, considerando los comentarios sobre el texto bíblico, de pasajes importantes del Deuteronomio recogidos por Ezequías, puestos a salvo durante la persecución de Manasés y perdidos después ${ }^{121}$. En el relato bíblico Josías aparece rasgándose las ropas mientras exclama: "grande es la ira de Yahvé que se ha encendido contra nosotros, por cuanto nuestros padres no han obedecido los mandamientos de este libro de hacer conforme a todo lo que ha sido escrito" (Reyes 2, 22,13). Implícitamente, en el relato de Buluqiya se deja traslucir el mismo avatar de la historia de Josías (el paroxismo de Buluqiya al ponerse en la cabeza el texto de la Torá, semejante al de Josías), al tiempo que la parábola del "hallazgo" que desarrollan los textos de Buluqiya y Ka'b parece encontrar en este pasaje bíblico su precedente más inmediato (el encuentro de una verdad sagrada ocultada por los antepasados del rey judío).

Siguiendo con los paralelos, según ha indicado Bencheikh ${ }^{122}$, Uxiyya (Uxri para el morisco), padre de Buluqiya, podría ser trasunto del propio Josías (Yūšiyā). Teniendo en cuenta que este rey judío descrito en el Antiguo Testamento no poseía ningún descendiente que respondiese al nombre de Buluqiya, cabría señalar que este nombre (el de Josías) habría sido introducido en el relato para sugerir la relación tipológica ${ }^{123}$ existente entre el descubrimiento por parte de Josías de las originales Escrituras y el hallazgo de la revelación de la venida de Mahoma apartada de su lugar original en el libro judío de la Torá. Igualmente, por el mismo proceso tipológico, el propio nombre de Buluqiya podría originarse en el de Hilqiya, el sacerdote que descubre el oculto Libro de la Ley ${ }^{124}$ y que el hadiz legendario sobre la conversión de Ka'b al-Aḥbār se habría encargado de convertir, como ya se observó, en el monje cristiano (Bulujya) que conoce junto al judío las escrituras ocultas sobre Mahoma.

120. Véase S.M. Olyan, «Ben Sira's Relationship to the Priesthood», Harvard Theological Review, 80:3 (1987), pp. 261-286.

121. J.E. BENCHEIKH, Les mille et une nuits ou la parole prisonnière, París, 1988, p. 186.

122. Ibídem.

123. Para la tipología aplicada a la literatura aljamiado-morisca véase D. ZUWIYYA, «A Typological Approach to Aljamiado-Morisco Literature», Qurțuba. Estudios Andalusies, 6 (2001), pp. 187-212; y «La literatura aljamiado-morisca: una interpretación tipológica», en Actas del VIII Simposio Internacional de Mudejarismo, 2 vols., Teruel, 2002, vol. 2, pp. 875-884.

124. Véase J. HorowiTz, «The Origins of the Arabian Nights», Islamic Culture, 1 (1917), pp. 52-53. 


\section{LOS “SIGNOS DE LA PROFECÍA" DE LA TRADICIÓN POLEMISTA ANDALUSÍ A LOS TEXTOS DE MUDÉJARES Y MORISCOS: UNA PROPUESTA METODOLÓGICA}

Existe la opinión comúnmente aceptada de que muchos relatos árabes fueron transmitidos por vía oral en la España musulmana de los siglos XV y XVI. Sin embargo, en el caso del relato aljamiado de Buluqiya, su parentesco con el texto original de las Qișaș al-anbiy $\bar{a}^{\prime}$ de at-Ta'labī es evidente, lo que sin duda apoya la hipótesis de que el romanceador mudéjar o morisco tenía a su alcance la misma tradición textual (matn) que se ha conservado en la obra del autor oriental muerto en el siglo XI. Las diferencias, por el contrario, estriban en algunas variantes relativas a los nombres propios y en una distinta atribución en cuanto a la transmisión del relato (isnād), si bien en ambas tradiciones se deja traslucir la autoridad última de 'Abd Allāh b. Salām. Parece indudable, por tanto, que hubo de conocerse la tradición en al-Ándalus mucho antes de ser recogida por los moriscos. Así las cosas, ¿cuándo se introdujo en la Península el relato de Buluqiya? Y lo que es más importante, ¿cuál sería el objeto final de su supuesta difusión? Pudo ser en época tardía, tal vez ya entrado el siglo XIII, cuando existiera una razón especialmente fundamentada por la que el texto incluido en la obra de at- $\underline{-} a^{\prime}$ labī gozara de verdadera difusión en al-Ándalus.

En las páginas que restan pretendo establecer la hipótesis de que los textos de mudéjares y moriscos mantuvieron viva la tradición hagiográfica andalusí, especialmente la del período tardío, destinada a contrarrestar el impulso de la disputatio antimusulmana de los mozárabes, que observaba de cerca la polémica suscitada en los textos islámicos sobre los "signos de la profecía" y cuyas fuentes nos permiten conocer que lo hacían: a) defendiendo las escrituras cristianas de la acusación de tahriîf ("corrupción") promovida en el Corán y las tradiciones; b) rebatiendo el dogma de la predestinación islámica en todas sus simbologías (idea del "sello de la profecía", etc.); y c) desacreditando la labor de los primitivos judíos y cristianos conversos al Islam que advierten de los "signos", tomando especialmente como referencia la Sìra de Ibn Ishāa ${ }^{125}$. De todo ello se podrá concluir que el "Fecho" de Buluqiya participa de todos los elementos literarios sintomáticos de esta polémica y que, además, la literatura de mudéjares y moriscos podría estar conservando en buena medida los textosbase que desarrollan parabólicamente los argumentos islámicos en torno a ella.

La época de los Ayyubíes en Egipto (1171-1260) vivió, en el ámbito literario religioso, un especial incremento de las obras de devoción a Mahoma, motivado

125. Para el temprano desarrollo de todos estos aspectos de la polémica mozárabe véase N. DANIEL, Islam and the West. The Making of an Image, Oxford, 1993, p. 17 y ss.; $y$ «Spanish Christian Sources of Information about Islam (Ninth-Thirteenth centuries)», al-Qanțara, 15 (1994), pp. 365-384. 
en gran medida por el reformismo de Abū Hāamid al-Gazālī (m. 1111), quien dedicó páginas completas al abordaje teológico sobre las pruebas de la profecía ${ }^{126}$. Que el relato de Buluqiya era conocido por al-Gazālī y que, además, existían allí y entonces diferentes tradiciones textuales del mismo lo demuestra que una de esas tradiciones, distinta de la filiada por at-Ta' ${ }^{\prime}$ labī y el anónimo morisco, se haya podido encontrar glosada en la obra epistolar ( $\left.r a s \bar{a}^{\prime} i l\right)$ del conocido teólogo ${ }^{127}$. Asimismo, el relato recensionado por at-Ta'labī hubo de adquirir en esta misma época una especial significación, como lo indica el hecho de que haya sido recogido por algunos de los autores que han escrito la historia de este período en Egipto: an-Nuwayrī (m. 1333) e Ibn Iyās (m. 1524) ${ }^{128}$.

La presencia documental del relato en esta época y ámbito del mundo islámico nos proporciona datos sumamente reveladores, y puesto que el reformismo almohade imperante en al-Ándalus entre los siglos XII y XIII iniciado de la mano de Ibn Tūmart (m. ca. 1130) entroncaba ideológicamente con el devocionalismo pietista de al-Gazālī, pudo ser precisamente en este período de tiempo cuando se introdujera el relato de Buluqiya en la Península. Por otra parte, es conocida la notable influencia que ejerció el imām al-Gazālī sobre los autores polemistas andalusíes tras la caída del poder almorávide, influjo que alcanza a los propios moriscos ${ }^{129}$, por lo que el texto de Buluqiya pudo penetrar en territorio peninsular con el impulso de sus propios argumentos anticristianos, no siempre basados en la doctrina estática y los testimonios bíblicos y sí ocasionalmente en una versátil hagiografía.

Precisamente, en este período encontramos un testimonio revelador de esta circunstancia. Se trata de la primera versión netamente andalusí de la leyenda del monje Baḥ̄rà, incluida en una obra titulada al-I'lām bimā fì dìn an-nașārà min al-fasād, wa-l-awhām, wa-iẓhār mahāasin dīn al-islām, wa-itbāt nubuwwat nabiyyinā Muhammad (Información de la corrupción y fantasías existentes en la religión de los cristianos, demostración de las bondades de la religión del Islam y prueba de la profecía de nuestro profeta Mahoma), compuesta por el imām llamado al-

126. Véase M. Asín Palacios, Algazel. Dogmática, moral, ascética, Zaragoza, 1901, pp. 152-177; y F. GrIfFel, «Al-Gazālī Concept of Prophecy: the Introduction of Avicennan Psychology into As'arite Theology», Arabic Sciences and Philosophy, 14 (2004), pp. 101-144.

127. Cfr. Mâymū'at rasā'il al-imām al-Gazālì, El Cairo, s.f., p. 545. El texto hace referencia al pasaje en que Buluqiya y 'Affān salen en busca del anillo de Salomón, que según esta recensión del relato sólo pudo ser tomado, pasado un largo tiempo, por el propio Profeta de los musulmanes, quien a su vez lo hizo entregar a su yerno y cuarto califa 'Alī b. Abī Ṭālib.

128. Cfr. Ibn Iyās, Badā' $i^{\prime}$ az-zuhūr fì waqā' $i^{\prime} a d-d u h \bar{u} r$, p. 155, quien cita como fuente primaria al propio at-Ta'labī. Para la presencia del autor oriental como informante principal de an-Nuwayrī en su monumental Nihāyat al-arab véase M.J. KISTER, op. cit., p. 228.

129. Véase la "Introducción" de M. Menéndez Pelayo a M. Asín PALACios, op. cit., p. 29; y el texto de la Tafsira del Mancebo de Arévalo, ed. de MaT. Narváez Córdoba, Madrid, Trotta, 2003, 41 et passim. 
Qurțubi ${ }^{130}$ hacia principios del siglo XIII ${ }^{131}$ a modo de contestación del Tațlit alwahdānīyya, texto de polémica antimusulmana escrito por un mozárabe toledano converso ${ }^{132}$, cuya argumentación se establece como contestación de los dogmas racionalistas de Ibn Tūmart ${ }^{133}$. No obstante, la obra de al-Qurțbī se enmarca en la tarea de refutación de los dogmas cristianos donde la figura de Mahoma se convierte en objeto de controversia a través del motivo de las "pruebas"o "signos de la profecía"134.

La narración del encuentro del monje siríaco Bahịrà con el joven Mahoma había llegado a al-Ándalus en el siglo IX junto al heterogéneo cuerpo narrativo que componen la Sìra y los Magāzi del Profeta ${ }^{135}$. En el siglo XI, si no antes, el relato era ya conocido por los mozárabes, tal y como lo prueba el más antiguo de los textos mozárabes de controversia que se ha conservado, el Liber denudationis (o Contrarietas alfolica) ${ }^{136}$, texto que conoció diferentes recensiones latinas durante toda la Edad Media. El anónimo autor de esta obra, al tratar de la formación de Mahoma, tomando como base la Sīra de Ibn Ishạa entre otras fuentes, describe la relación de aquél con el monje cristiano Bahịìa (Boheira), el judío 'Abd Allāh b. Salām (Abdalla filius Selam) y el persa Silmān al-Fārisī (Salon Persa), citando igualmente como prueba un tradición que demostraría el grado de magisterio que éstos ejercieron en Mahoma ${ }^{137}$. Como se comprobará, la cita constituye toda una alusión desmitificadora de la sección de la obra de Ibn

130. Para una posible identificación de este autor con la figura de Abū Ŷa'far b. Nașr ar-Rawadī véase M. de EPALZA, «Notes pour une histoire des polémiques anti-chrétiennes dans l'Occident musulman», Arabica, 18 (1971), p. 104.

131. Véase J.P. MONFERrer SALA, op. cit., p. 142.

132. Para la hipótesis de atribución de esta obra de polémica antimusulmana a Pedro Alfonso véase P. VAN KONINGSVELD, «La apología de al-Kindī en la España del siglo XII. Huellas toledanas de un 'animal disputax'», en Estudios sobre Alfonso VI y la reconquista de Toledo. Actas del II Congreso Internacional de Estudios Mozárabes, 4 vols., Toledo, 1987, vol. 3, pp. 127-129.

133. Véase D. Unvoy, «Le pensée d'Ibn Tūmart», Bulletin d'Études Orientales, 27 (1974), p. 23 y ss.

134. Véase el estudio del al-I'lām dedicado por A. AIT BELAID, «La profecía de Mahoma a través de la Biblia Sagrada», Anaquel de Estudios Árabes, 16 (2005), pp. 65-81.

135. Véase a este respecto J.M ${ }^{a}$ FóRNEAS, «La primitiva Sīra de Ibn Ishāa en al-Andalus», en Homenaje al Profesor Jacinto Bosch Vilá, 2 vols., Granada, Universidad, 1991, vol. 1, pp. 145-179. La cita más temprana de la biografía de Mahoma en la tradición cristiana peninsular se encuentra en Eulogio, Liber apoleticus martyrum, 16 (véase Corpus Scriptorum Muzarabicorum, 2 vols., ed. J. Gil Fernández, Madrid, 1973, vol. 2, pp. 483-486; K. Wolf, «The Earliest Latin Lives of Muhammad», en M. Gervers y R. BIKHAZI (eds.), Conversion and Continuity: Indigenous Christian Communities in Islamic Lands, Eighth to Eighteenth Centuries, Toronto, 1990, pp. 89-101).

136. Para la edición de esta obra consúltese Th.E. BURMAn, Religious Polemic and the Intellectual History of the Mozarabs (c. 1050-1200). Leiden-Nueva York-Colonia, 1994.

137. Ibídem, pp. 41-42 y 270 para el texto latino; véase igualmente J.P. MONFERRER SALA, op. cit., p. 141; idea a su vez tomada de al-Kindī, quien también cita a 'Abd Allāh b. Salām (Th. E. BuRMAN, op. cit., p. 122). 
Ishạaq que hacía referencia a la anunciación de Mahoma por monjes cristianos y doctores judíos y que constituye la base dogmática de toda la literatura sobre los "signos de la profecía" en el Islam. En este contexto, la tradición de Buluqiya, puesta en boca de uno de esos judíos conversos que cita el texto mozárabe, apremiaría, en un grado de intelección popular, a desmentir estas opiniones vertidas por los apologistas cristianos sobre estos importantes correligionarios del Islam primitivo ${ }^{138}$; lo mismo que sucedería, tal vez, en el caso del también mentado Silmān al-Fārisī, con respecto a la narración del monje cristiano Sarŷīl ibnu Sarŷūn.

Los relatos de las primeras conversiones al Islam, tan extendidos como hemos visto en la tradición morisca por su valor apologético, tampoco pasaron inadvertidos para los polemistas cristianos andalusíes, y en el capítulo $4^{\circ}$ del Liber denudationis ya se nos advierte de las "falsas historias" de la conversión de algunos ilustres musulmanes (cita la de ‘Umar, que se conserva también en aljamiado ${ }^{139}$ ).

Una de las historias sobre la vida de Mahoma más difundidas entre los moriscos fue sin duda el Kitāb al-anwāar de Abū-l-Hasan al-Bakrī (s. XIII), algunas de cuyas versiones aljamiadas integran el relato del encuentro de Mahoma con el monje Bahīrà ${ }^{140}$. La narración del Libro de las luces, del que se conservan numerosos manuscritos moriscos ${ }^{141}$, elabora la teoría de la iluminación espiritual que privilegia a Mahoma y que, por consiguiente, reclama la supremacía del Islam desde antes de la creación y sobre todas las demás religiones. Tal iluminación se correspondería, pues, con el signo de la condición profética que se habría ido transmitiendo ininterrumpidamente hasta Mahoma a través de todos los miembros del linaje de Adán. El interés entre los mozárabes de esta doctrina de la predestinación, fundamentada en la idea de que el profetismo mahomético es auspiciado desde los tiempos de la Creación, se remonta ya a las referencias del propio Eulogio de Córdoba en el Memoriale Sanctorum sobre la inscripción en los cielos del nombre de Mahoma:

"Se dice que, cuando todavía moraba en el paraíso, el rudo primer hombre, al contemplar el nombre de aquél inscrito en las alturas y envuelto en un halo de luz resplandeciente, preguntó al Creador qué era aquella luz que brillaba en el cielo más intensamente que las demás y cuyo resplandor homenajeaba a Dios; y Él le respondió: he aquí el verdadero profeta que ha de venir al mundo y que, na-

138. La desacreditación de la labor de estos primeros judíos o cristianos conversos al Islam es un aspecto muy difundido en la cristiandad medieval, pues aparece en las anotaciones de Robert de Ketton a la traducción latina del Corán (véase Th.E. BuRMAN, op. cit., p. 85).

139. Ms. BNM 4953, fols. 78v-90r, editado por O. HEGYI, op. cit., pp. 138-149.

140. Cfr. ms. BNM 4955.

141. Además del arriba mencionado ms. BNM 4955, súmense también los mss. BPR 3226, BRAH (Gayangos T.17), etc. 
cido de tu semilla, llevará ese mismo nombre que ves atónito destellar, Mahoma, por cuyos méritos tú has merecido ser creado" ${ }^{\prime 142}$.

Teoría de la predestinación islámica que aparece también desarrollada en el relato de Buluqiya, adscrita a la šahäda o acto de fe que debe reconocer todo musulmán:

“...y sepas, Buluqiya, que no hay entrada de puerta que no esté en cada puerta [del paraíso y del infierno] la palabra de lā ilāha illā Allāh / Muhammad rasūlu llāh [=No hay más Dios que Alá y Mahoma es su mensajero], y por aquesta razón conocemos a Muhammad" ${ }^{143}$.

La cita se plantea sobre las mismas premisas que la doctrina de la inscripción de la šahāda en el trono de Dios, a la que ya hacían referencia Bartolomé de Edessa y al-Kindi ${ }^{144}$. No obstante, el cristianismo europeo medieval sintió gran interés por este topos que desarrolla el dogma de la predestinación mahomética, y una de las versiones más conocidas de esta tradición, la recogida en el Kitāb nasab ar-rasūl, de Sa'īd b. 'Umar, fue traducida al latín en 1142 por Hermann de Dalmacia con el título de Liber generationis Mahumet ${ }^{145}$, seguramente por vía mozárabe. Se da la circunstancia de que se conservan fragmentos en la literatura aljamiado-morisca de la obra de Sa'îd b. 'Umar (Said fijo de Omar), uno de los cuales se halla inserto en el mismo manuscrito (Junta VIII) que contiene el relato de Buluqiya ${ }^{146}$. Esta obra hubo de adquirir una especial relevancia entre los últimos musulmanes hispánicos, pues Janette Becerra ha sugerido que el autor morisco del "Discurso de la Luz", Mohamed Rabadán, se valió de la versión de Sa'īd b. 'Umar para llenar la laguna (unas 19 generaciones) que quedó en el Libro de las Luces de al-Bakrīin ${ }^{147}$.

Así, pues, sólo un análisis codicológico de estos manuscritos, y en general de la producción aljamiada que hemos ido citando a lo largo de las páginas precedentes, permitiría abordar su estudio de conjunto sobre criterios algo más firmes de lo habitual en este campo y facilitaría en gran medida el ras-

142. Cfr. Eulogio, Memoriale, vol. 1/12, pp. 5-19, en op. cit., pp. 378-379.

143. Ms. Junta VIII, fol. 85r.

144. Para Bartolomé de Edessa remito a J.P. Migne, Patrologia Graeca, 161 vols., París, 1857-1866, vol. 104, 1392b; para al-Kindī véase G. TARTAR, Dialogue islamo-chrétien sous le calife Al-Ma'mūm (813-834): les épitres d'Al-Hashimī et d'Al-Kindī, París, 1985, pp. 203-204.

145. Véase N. DANIEL, op. cit., pp. 39 y 57, n. 74.

146. Ms. Junta VIII, fols. 1r-18r; véase también ms. Junta IX, fols. 1r-16v.

147. Véase J. BECERRA, «La otra leyenda de las luces: nuevos acercamientos al manuscrito aljamiado J-9», en A. TEMIMI (ed.), Hommage à l'École d'Oviedo d'Études Aljamiado (dedié au fondateur Álvaro Galmés de Fuentes), Zaghouan, 2003, pp. 85-108. 
treo, no sólo material sino también en el tiempo, de sus fuentes textuales más próximas en la producción árabe ${ }^{148}$.

\title{
RESUMEN
}

El relato de Buluqiya, que se conserva en las tradiciones árabe y aljamiada, representa una tipología de textos adscritos a la literatura de tradición islámica que incluye múltiples segmentos narrativos del género apologético-polemista. El presente trabajo aborda el topos de los "signos de la profecía" desde la perspectiva de la mencionada narración y su relación tanto con el contexto ideológico islámico que lo determina como con otros textos representativos de la tradición igualmente conservados en la literatura de los moriscos.

Palabras clave: Signos de la profecía, Buluqiya, Gentes del Libro, apologética / polémica, escatología.

\begin{abstract}
The tale of Buluqiya, conserved in both arabic and aljamiado traditions, represents a tipology of texts assigned to the Literature of Islamic tradition that includes manifold narrative segments of the apologetic-polemicist genre. This paper approaches the topic of the "signs of prophecy" from the perspective of the above mentioned tale and its relation with the Islamic ideological context that determines it as much as other representative texts of this tradition preserved in morisco Literature.
\end{abstract}

Key words: Signs of prophecy, Buluqiya, People of the Book, apologetic/ controversy, eschatology.

148. Ya hace años A. Montaner Frutos alentó a trabajar sobre este criterio de análisis, en «El depósito de Almonacid y la producción de la literatura aljamiada (en torno al ms. misceláneo xiii)», Archivo de Filología Aragonesa, 41 (1988), pp. 119-152. 